\title{
Synthesis, Characterization and Biological Activity of Saturated and Unsaturated Copolyesters Based on Bisphenol-A
}

\author{
Ahmed Abd-Elsalam Khalil, Amal A.Mahmoud and Laila \\ M.Reda \\ Chemistry Department, Faculty of Science, Benha University, \\ Benha, Egypt.
}

\begin{abstract}
SATURATED copolyesters were prepared by copolyesterfication of bisphenol-A (BPA) and phthalic anhydride or tetrabromophthalic anhydride with ethylene glycol, diethylene glycol, 1,3-propane diol, 1,5-pentane diol, 1,6-hexane diol and cis-2-butene-1,4-diol. Also, unsaturated copolyesters were prepared by copolyesterification of bisphenol-A and maleic anhydride with the same glycols. All the copolyester resins obtained have been characterized; unsaturated copolyesters were found to cure with styrene. The properties of the copolyester in the form of films were determined. Also, the fire retardancy of polyesters was evaluated as varnish films on plywood strips. IR and ${ }^{1} \mathrm{HNMR}$ spectroscopy were used for characterization of the copolyester resins. The antimicrobial activity of the copolyesters obtained was examined against gram-positive and gram-negative bacteria.
\end{abstract}

Keywords: Copolyesters, Tetrabromophthalic anhydride glycols, Bisphenol-A and Antimicrobial activity.

Bisphenol-A (BPA) is a high-volume production chemical used to make epoxy resins and polycarbonate plastic products, including some kinds of water bottles, baby bottles, and food storage and heating containers ${ }^{(1)}$. It is also used in the lining of metal food cans and in dental sealants, and is an additive to certain plastics used in children's toys. The chemical was first developed as a synthetic estrogen and was later polymerized to produce polycarbonate. Bisphenol-A mimics estrogen activity and is known as an "endocrine disruptor," a chemical that interferes with the hormonal system in animals and humans and contributes to adverse health effects. Bisphenol-A also causes a variety of impacts through mechanisms of action that are probably unrelated to estrogenic properties ${ }^{(2-5)}$. It is also a precursor to the flame retardant polymers ${ }^{(6-8)}$.

Saturated and unsaturated polyesters are conveniently prepared by melt copolyesterfication at elevated temperature above the melting point of the reactant ${ }^{(9,10)}$. Curing of the unsaturated polyesters with styrene to form solid thermoset materials may have markedly improved properties ${ }^{, 9,11)}$. It was stated previously $^{(12,13)}$ that, some polyesters were prepared by the reaction of bis- 
(dicarboxymethoxy)benzene phthalic anhydride and maleic anhydride with some glycols. In the present work, the synthesis of polyesters based on the condesation of bisphenol-A with phthalic anhydride, tetrabromophthalic anhydride and maleic anhydride with some glycols are described and their biological activity screened. Further, the aim was to investigate the factors affecting reactions between the unsaturated copolyesters and styrene.

\section{Materials}

\section{Experimental}

Maleic ahydride, phthalic anhydride, tetrabromophthalic anhydride and phenol benzoyl peroxide, styrene monomer, glycols (ethylene glycol, diethylene glycol, 1,3-propane diol, 1,5-pentane diol, 1,6-hexane diol and cis-2-butene-1,4diol), dimethyl formamide (DMF), chloroform and dioxane were obtained from Aldrich, BDH, Merck and were employed as received.

\section{Preparation of bisphenol-A}

Bisphenol-A was prepared by the condensation of acetone with two equivalents of phenol in the presence of sulphuric acid ${ }^{(14)}$

\section{Methods}

\section{Polyesterification reactions}

Bulk polyesterification reactions were carried out by the reaction of Bisphenol-A with acid anhydride and diols. Thus, the copolyesters were prepared by the reaction of bisphenol-A and acid anhydride [phthalic anhydride, tetrabromophthalic anhydride or maleic anhydride] with glycol in the molar ratio 1: $2: 1$, respectively. The reactions were carried out by heating the mixture in the presence of oxygen-free nitrogen. The time-temperature program for each copolyester is illusterated in Tables $1 \& 2$. The copolyesters prepared were purified twice from chloroform solution by precipitation with light petroleum and then dried under reduced pressure.

\section{Curing of polyester resins}

The unsaturated polyester prepared in each case was cured ${ }^{(15)}$ with styrene, in the weight ratio of 70:30, using benzoyl peroxide as a free radical initiator (1\%) weight ratio and dioxane as solvent. The cured copolyesters were casted as films on glass and tin plates. The plates were subjected to aging at $70^{\circ} \mathrm{C}$ for $24 \mathrm{hr}$, at $100^{\circ} \mathrm{C}$ for $24 \mathrm{hr}$, at $130^{\circ} \mathrm{C}$ for $6 \mathrm{hr}$, and finally, at $150^{\circ} \mathrm{C}$ for $6 \mathrm{hr}$. The films were tested for their resistance to acid and alkali solutions ${ }^{(16)}$ and to cold and hot water ${ }^{(17)}$.

The cured copolyesters were subjected to alkaline hydrolysis according to the method reported earlier ${ }^{(18)}$. The product in each case was characterized by studying its IR and ${ }^{1} \mathrm{HNMR}$ spectra. 
SYNTHESIS, CHARACTERIZATION AND BIOLOGICAL ACTIVITY ...

TABLE 1. Time-temperature programs for saturated copolyesters (I-XII) .

\begin{tabular}{||c|c|c|c|c|c|c||}
\hline \multirow{3}{*}{ Temp ${ }^{\mathbf{0}} \mathbf{C}$} & \multicolumn{7}{|c||}{ Time (min) } \\
\cline { 2 - 8 } & \multicolumn{7}{|c||}{ Saturated copolyesters } \\
\cline { 2 - 8 } & I & II & III & IV & V & VI \\
\hline \hline 70 & - & 30 & 30 & 30 & 30 & 30 \\
\hline 80 & 60 & 30 & 30 & 30 & 30 & 30 \\
\hline 90 & - & 30 & 30 & 30 & 30 & 30 \\
\hline 100 & 60 & 30 & 30 & 30 & 30 & 30 \\
\hline 110 & - & 30 & 30 & 30 & 30 & 30 \\
\hline 120 & 60 & 30 & 30 & 30 & 30 & 30 \\
\hline 130 & - & 30 & 30 & 30 & 30 & 30 \\
\hline 140 & 60 & 30 & 30 & 30 & 30 & 30 \\
\hline 150 & - & 30 & 30 & 30 & 30 & 30 \\
\hline 160 & 60 & 30 & 30 & 30 & 30 & 30 \\
\hline 170 & - & 30 & 30 & 30 & 30 & 30 \\
\hline 180 & 60 & 30 & 30 & 30 & 30 & 30 \\
\hline 190 & - & 30 & - & - & 30 & 30 \\
\hline 200 & 60 & - & - & - & - & 30 \\
\hline 210 & - & - & - & - & - & - \\
\hline 220 & 60 & - & - & - & - & - \\
\hline 230 & - & - & - & - & - & - \\
\hline 240 & 60 & - & - & - & - & - \\
\hline 250 & - & - & - & - & - & - \\
\hline 260 & 60 & - & - & - & - & - \\
\hline
\end{tabular}

TABLE 1. Cont.

\begin{tabular}{||c|c|c|c|c|c|c||}
\hline \multirow{3}{*}{ Temp. ${ }^{\circ} \mathbf{C}$} & \multicolumn{7}{|c||}{ Time (min) } \\
\cline { 2 - 7 } & \multicolumn{7}{|c||}{ Saturated copolyesters } \\
\cline { 2 - 7 } & VII & VIII & IX & X & XI & X II \\
\hline \hline 70 & 30 & - & - & - & - & - \\
\hline 80 & 30 & 60 & - & - & - & - \\
\hline 90 & 30 & - & - & 30 & - & 30 \\
\hline 100 & 30 & 60 & 30 & 30 & 30 & 30 \\
\hline 110 & 30 & - & 30 & 30 & 30 & 30 \\
\hline 120 & 30 & 60 & 30 & 30 & 30 & 30 \\
\hline 130 & 30 & - & 30 & 30 & 30 & 30 \\
\hline 140 & 30 & 60 & 30 & 30 & 30 & 30 \\
\hline 150 & 30 & - & 30 & 30 & 30 & 30 \\
\hline 160 & 30 & 60 & 30 & 30 & 30 & 30 \\
\hline 170 & 30 & - & 30 & 30 & - & 30 \\
\hline 180 & 30 & 60 & - & - & 30 & - \\
\hline 190 & 30 & - & - & - & - & - \\
\hline 200 & - & 60 & - & - & - & - \\
\hline 210 & - & - & - & - & - & - \\
\hline 220 & - & 60 & - & - & - & - \\
\hline \hline
\end{tabular}


TABLE 2. Physical properties of saturated copolyester resins (I-XII).

\begin{tabular}{|c|l|c|c|c|c||}
\hline Polyester & Nature of polyester & Med. Wt & Acid value & $\mathbf{n}$ & $\eta_{\text {int }}$ \\
\hline \hline I & Viscous material & 4007 & 25.1 & 7 & 0.0671 \\
\hline II & Viscous material & 1336 & 84.1 & 2.18 & 0.0231 \\
\hline III & Viscous material & 2671 & 42 & 4.5 & 0.0524 \\
\hline IV & Low melting solid & 1002 & 112.2 & 1.6 & 0.0354 \\
\hline V & Viscous material & 4007 & 28 & 6.5 & 0.084 \\
\hline VI & Viscous material & 2004 & 56.11 & 3.2 & 0.0233 \\
\hline VII & Viscous material & 8014 & 14 & 6.8 & 0.0981 \\
\hline VIII & Viscous material & 8014 & 14 & 6.5 & 0.0415 \\
\hline IX & Viscous material & 4007 & 28 & 3.36 & 0.0561 \\
\hline X & Viscous material & 2003 & 56.11 & 1.66 & 0.0854 \\
\hline XI & Viscous material & 8014 & 14 & 6.57 & 0.0724 \\
\hline XII & Viscous material & 4007 & 28 & 3.2 & 0.0651 \\
\hline
\end{tabular}

Characterization of polyesters

Viscosity measurements were carried out by an Ostwald viscometer using a $1 \%$ by weight solution in dioxane at $30^{\circ} \mathrm{C}$. The average molecular weight of the prepared copolyesters were determined by the end-group analysis for carboxylic groups using $\mathrm{KOH}^{(19)}$. IR spectra were recorded $(\mathrm{KBr}$ pellet) on a Pye-Unicam Sp-883 Perkin Elmer spectrophotometer. ${ }^{1} \mathrm{H}$ NMR spectra were recorded on a Varian Gemini 200 spectrometer, operating at $200 \mathrm{MHz}$ for proton; Cairo University.

\section{Preparation of varnish films}

Polywood of dimensions $5 \times 0.5 \times 0.05 \mathrm{~cm}$ were varnished by dipping in solution of polyester in DMFR . The weight of the dried varnish film is equal to the difference between the weight of polywood strip before and after dipping. The strips are prepared for flammability test.

\section{Results and Discussion}

Synthesis and structure of saturated copolyester resins

In the present study, saturated copolyesters (1-VI) were synthesized by the reaction of bisphenol-A and phthalic anhydride with ethylene glycol, diethylene glycol, 1,3-propane diol, cis-2-butene-1,4-diol, 1,5-pentanediol and 1,6-hexane thylene diol.

Egypt. J. Text. Polym. Sci. Technol. 14, No. 2 (2010) 
The structure of the prepared copolyesters (I-VI) can be illustrated as follows:<smiles>CC(C)(c1ccc(O)cc1)c1ccc(O[OH2+])cc1</smiles>

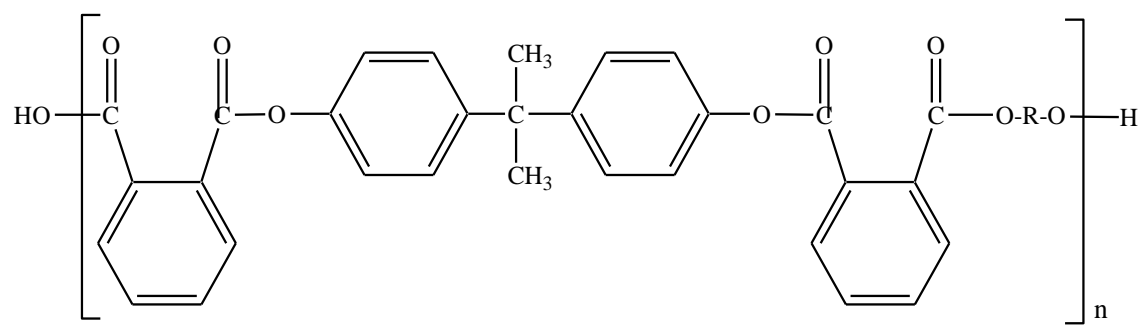

(I-VI)

\section{Where:}

$$
\begin{array}{ll}
\mathrm{R}=\mathrm{I}, & -\mathrm{CH}_{2}-\mathrm{CH}_{2-}^{-} \\
\mathrm{II}, & -\mathrm{CH}_{2} \mathrm{CH}_{2} \mathrm{OCH}_{2} \mathrm{CH}_{2-}^{-} \\
\mathrm{III}, & -\mathrm{CH}_{2} \mathrm{CH}_{2} \mathrm{CH}_{2}^{-} \\
\mathrm{IV}, & -\mathrm{CH}_{2}-\mathrm{CH}=\mathrm{CH}-\mathrm{CH}_{2} \\
\mathrm{~V}, & -\mathrm{CH}_{2} \mathrm{CH}_{2} \mathrm{CH}_{2} \mathrm{CH}_{2} \mathrm{CH}_{2-}^{-} \\
\text {VI }, & -\mathrm{CH}_{2} \mathrm{CH}_{2} \mathrm{CH}_{2} \mathrm{CH}_{2} \mathrm{CH}_{2} \mathrm{CH}_{2}-
\end{array}
$$

Also, saturated copolyesters containing bromine (VII, XII) were prepared similarly by the reaction of bisphenol-A and tetrabromophthalic anhydride with the same glycols. 
The structure of the prepared copolyesters (VII, XII) can be illustrated as follows:
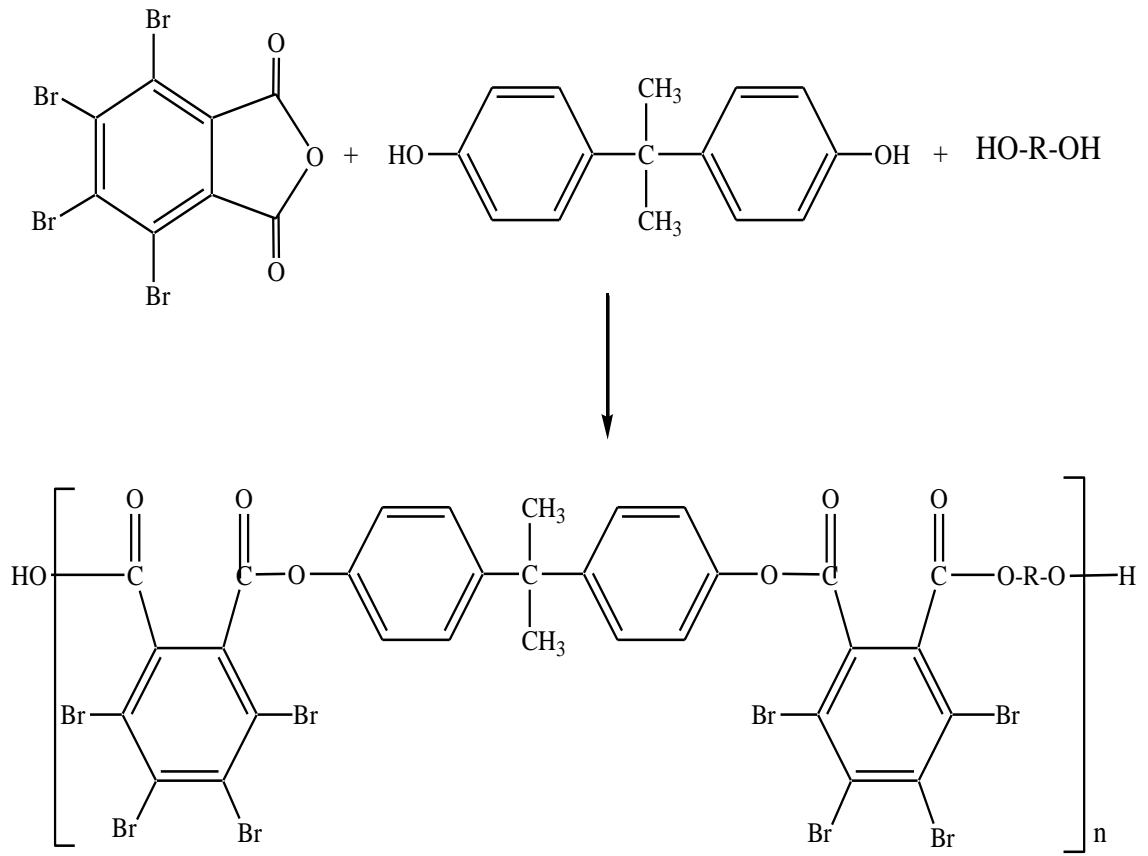

\section{Where}

$$
\begin{array}{cl}
\mathrm{R}=\mathrm{VII}, & -\mathrm{CH}_{2}-\mathrm{CH}_{2^{-}} \\
\text {VIII }, & -\mathrm{CH}_{2} \mathrm{CH}_{2} \mathrm{OCH}_{2} \mathrm{CH}_{2^{-}} \\
\mathrm{IX}, & -\mathrm{CH}_{2} \mathrm{CH}_{2} \mathrm{CH}_{2-}^{-} \\
\mathrm{X}, & -\mathrm{CH}_{2}-\mathrm{CH}=\mathrm{CH}-\mathrm{CH}_{2} \\
\mathrm{XI}, & -\mathrm{CH}_{2} \mathrm{CH}_{2} \mathrm{CH}_{2} \mathrm{CH}_{2} \mathrm{CH}_{2-}^{-} \\
\text {XII, } & -\mathrm{CH}_{2} \mathrm{CH}_{2} \mathrm{CH}_{2} \mathrm{CH}_{2} \mathrm{CH}_{2} \mathrm{CH}_{2}
\end{array}
$$

The time-temperature program for each copolyester is illusterated in Table 1. 
SYNTHESIS, CHARACTERIZATION AND BIOLOGICAL ACTIVITY ...

Fig. 1\&2 shows the acid number versus time of unsaturated copolyester resins (I-XII).

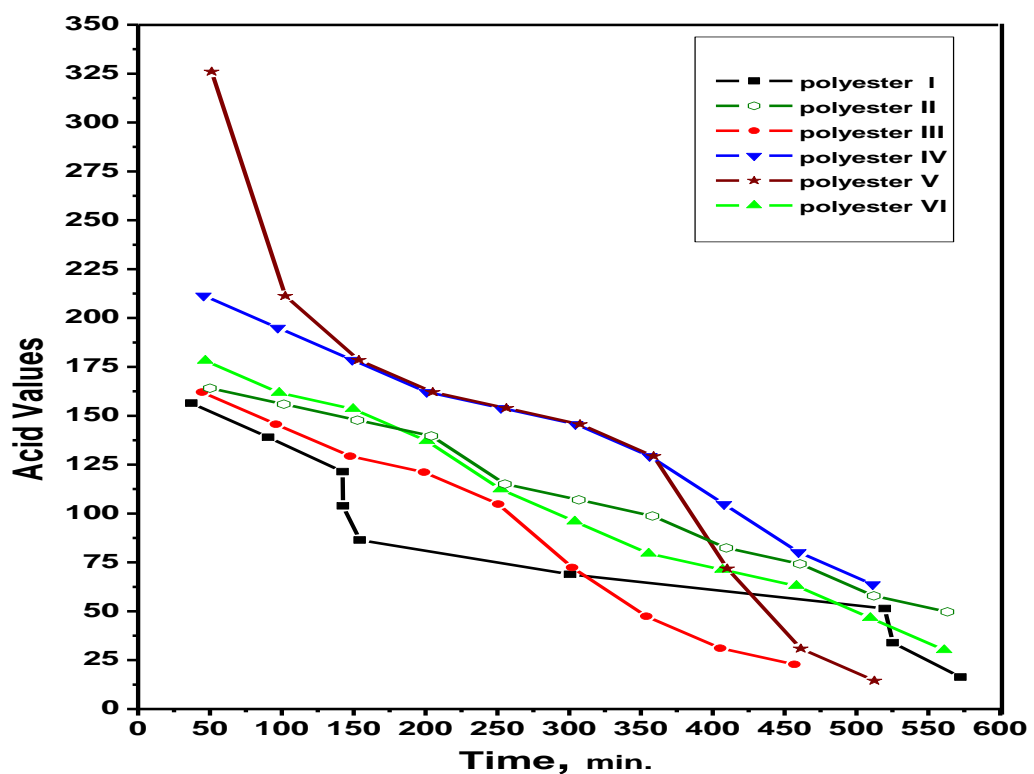

Fig. 1. The acid number versus time for saturated copolyesters resin .

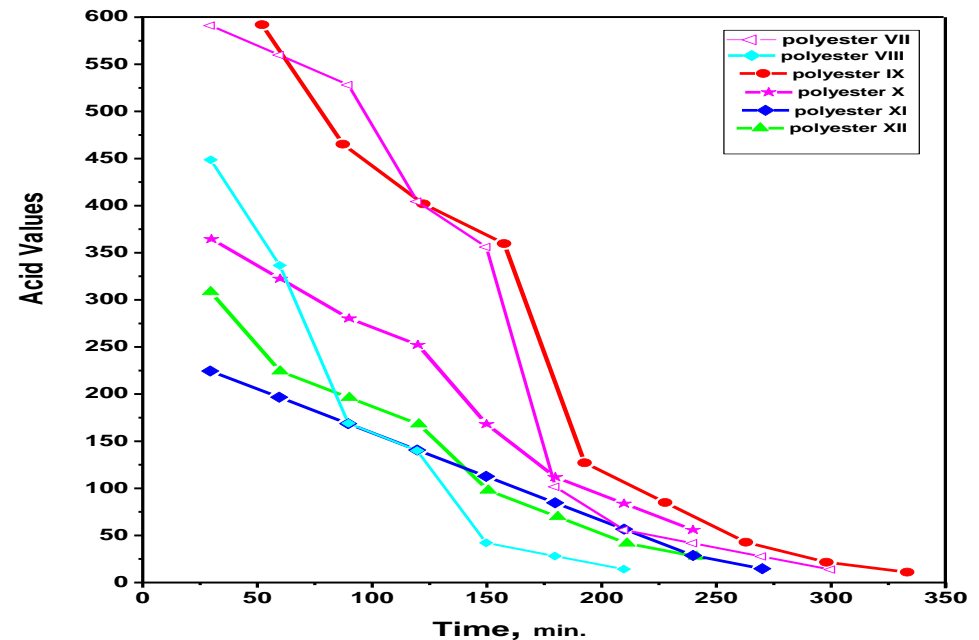

Fig. 2. The acid number versus time for saturated copolyesters resin.(VII-XII). 
The structure of the prepared copolyesters was established by studying their IR and ${ }^{1}$ HNMR spectra. The IR spectra of the prepared copolyesters showed absorption bands at $3485-3417 \mathrm{~cm}^{-1}$ of $\mu_{\mathrm{OH}}, 2950-2920 \mathrm{~cm}^{-1} \mu_{\mathrm{CH}_{2}}$ (aliphatic) and $1735-1720 \mathrm{~cm}^{-1} \mu_{C=0}$ (ester).

The ${ }^{1}$ HNMR spectra of copolyester (V) showed signals at $\delta 6.5-8.2(\mathrm{~m}, 16 \mathrm{H})$ due to aromatic protons, at $\delta 4.2$ due to aliphatic protons $\left(-\mathrm{CH}_{2} \mathrm{OCO}\right)$ group, at 80.7-1.7 due to two methyl groups of bisphenol- $\mathrm{A}$ and $-\mathrm{CH}_{2}$ group as shown in Fig. 3.

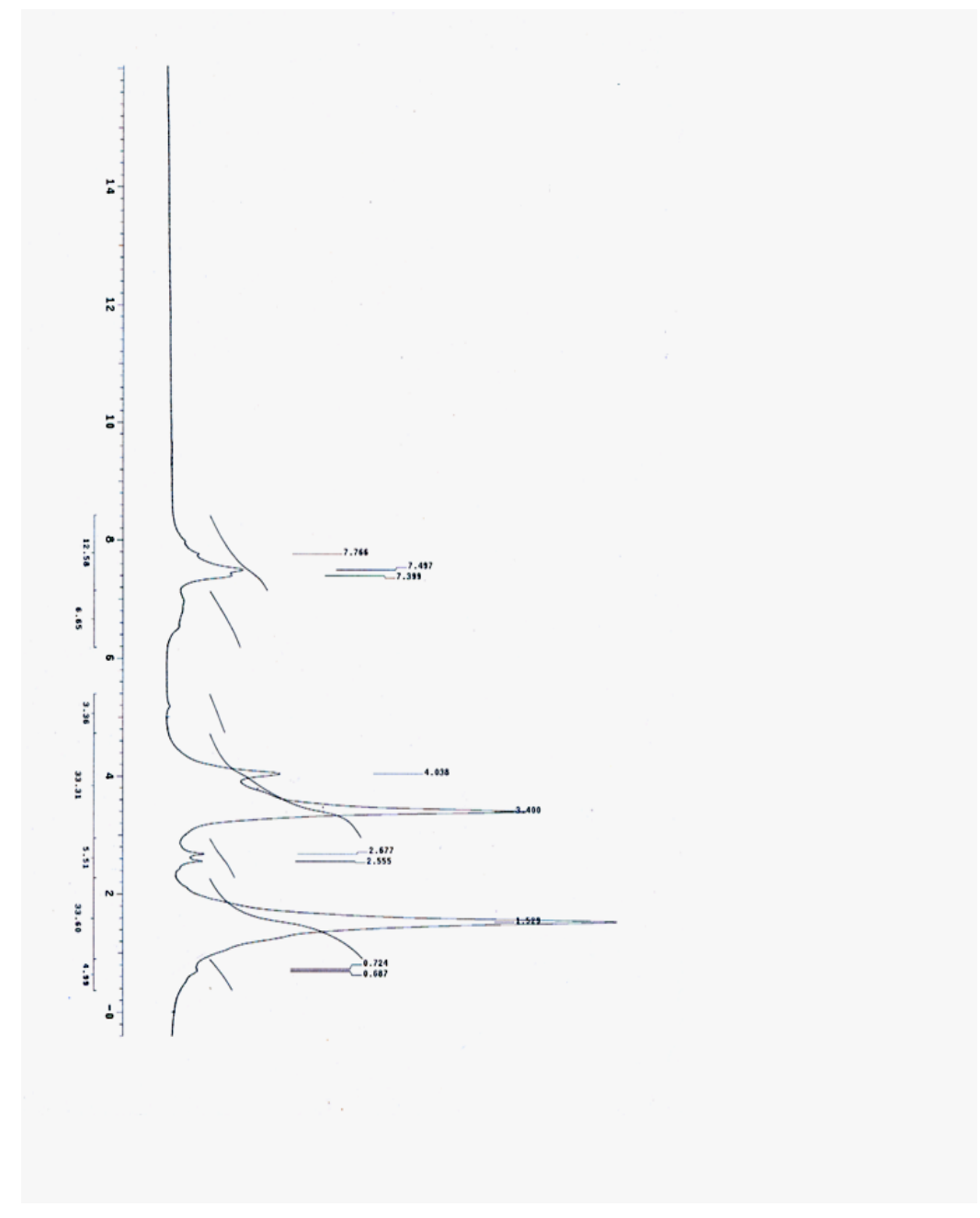

Fig. 3. ${ }^{1}$ HNMR spectrum of copolyester (V).

Egypt. J. Text. Polym. Sci. Technol. 14, No. 2 (2010) 
SYNTHESIS, CHARACTERIZATION AND BIOLOGICAL ACTIVITY ..

Physical properties of saturated copolyester resins:

The prepared copolyesters (I-XII) were yellowish to dark brown viscous materials, soluble in various organic solvents except ethanol, n- hexane and light petroleum ether. These linear copolyesters showed great resistance to gelation after long storage periods. Some of the physical properties (acid value, molecular weight, number of repeating units and viscosity measurements) of the prepared copolyesters are illustrated in Table 2. From Table 2 it is clear that the molecular weight of the prepared copolyester resins ranged from 1002 to 8014 .

Synthesis and structure of unsaturated copolyester resins

Also, in the present work, unsaturated copolyesters containing maleate unsaturation (XIII- XVIII) were prepared by the reaction of bisphenol-A and maleic anhydride with the following glycols: ethylene glycol, diethylene glycol, 1, 2- propane diol, cis-2- butene-1,4-diol, 1,5-pentane diol, and 1,6-hexane diol as follows:<smiles>CC(C)(c1ccc(O)cc1)c1ccc(O)cc1</smiles>

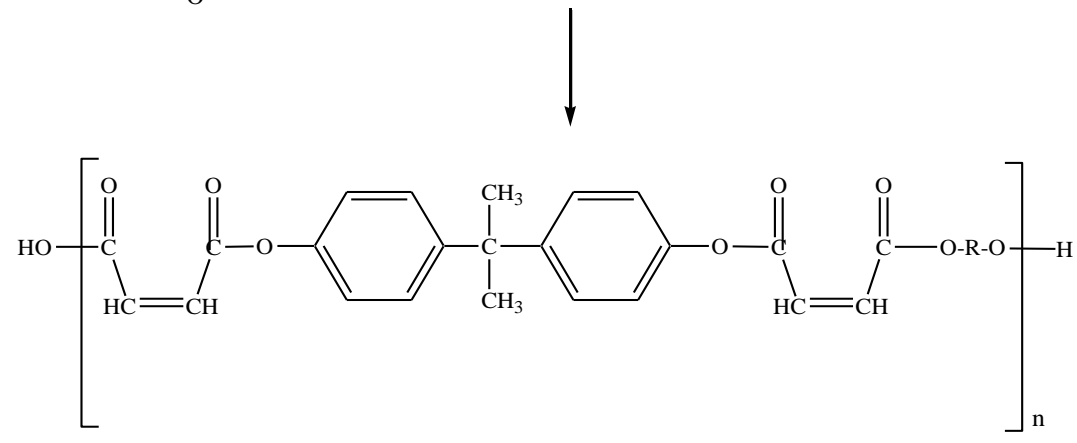

(IX-XV)

Where

$$
\begin{aligned}
& \mathrm{R}=\mathrm{XIII},-\mathrm{CH}_{2}-\mathrm{CH}_{2}- \\
& \mathrm{XIV},-\mathrm{CH}_{2} \mathrm{CH}_{2} \mathrm{OCH}_{2} \mathrm{CH}_{2}- \\
& \mathrm{XV} \text {, } \\
& \underset{\stackrel{\mathrm{C}}{\mathrm{C}}-\mathrm{CH}_{3}}{\mathrm{H}}
\end{aligned}
$$

$\mathrm{XVI},-\mathrm{CH}_{2}-\mathrm{CH}=\mathrm{CH}-\mathrm{CH}_{2}$

XVII, $-\mathrm{CH}_{2} \mathrm{CH}_{2} \mathrm{CH}_{2} \mathrm{CH}_{2} \mathrm{CH}_{2}-$

XVIII, - $\mathrm{CH}_{2} \mathrm{CH}_{2} \mathrm{CH}_{2} \mathrm{CH}_{2} \mathrm{CH}_{2} \mathrm{CH}_{2}-$

Egypt. J. Text. Polym. Sci. Technol. 14, No. 2 (2010) 
The time-temperature program for each copolyester is illusterated in Table 3. Fig. 4 shows the acid number versus time (XIII-XVIII).

TABLE 3. Time-temperature programs for unsaturated copolyesters (XIII - XVIII).

\begin{tabular}{|c|c|c|c|c|c|c||}
\hline \multirow{2}{*}{ Temp. ${ }^{\mathbf{0}} \mathbf{C}$} & \multicolumn{6}{|c|}{ Time (min) } \\
\cline { 2 - 8 } & \multicolumn{6}{|c|}{ Unsaturated copolyesters } \\
\cline { 2 - 8 } & XIII & XIV & XV & XVI & XVII & XVIII \\
\hline \hline 70 & 30 & 30 & 60 & 30 & 30 & 30 \\
\hline 80 & 30 & 30 & - & 30 & 30 & 30 \\
\hline 90 & 30 & 30 & 60 & 30 & 30 & 30 \\
\hline 100 & 30 & 30 & - & 30 & 30 & 30 \\
\hline 110 & 30 & 30 & 60 & 30 & 30 & 30 \\
\hline 120 & 30 & 30 & - & 30 & 30 & 30 \\
\hline 130 & 30 & 30 & 60 & 30 & 30 & 30 \\
\hline 140 & 30 & 30 & - & 30 & 30 & 30 \\
\hline 150 & 30 & 30 & 60 & 30 & 30 & 30 \\
\hline 160 & 30 & 30 & - & - & 30 & 30 \\
\hline 170 & 30 & 30 & 60 & - & 30 & 30 \\
\hline 180 & 30 & 30 & 30 & - & 30 & 30 \\
\hline 190 & 30 & 30 & 30 & - & 30 & - \\
\hline 200 & - & - & 30 & - & 30 & - \\
\hline 210 & - & - & 30 & - & 30 & - \\
\hline & & & & & & \\
\hline
\end{tabular}

The structure of the prepared copolyesters was established by studying their IR and ${ }^{1} \mathrm{HNMR}$ spectra. The IR spectra of some prepared copolyesters showed bands at $3450-3400 \mathrm{~cm}^{-1}\left(v_{\mathrm{OH}}\right), 2920-2900 \mathrm{~cm}^{-1} v_{\mathrm{CH} 2}$ (aliphatic) and 1720-1700 $\mathrm{cm}^{-1} v_{\mathrm{C}-\mathrm{O}}($ ester $)$.

The ${ }^{1} \mathrm{HNMR}$ spectra of copolyester showed signals at $\delta 6.2-8.0(\mathrm{~m}, 12 \mathrm{H})$ due to aromatic protons and $-\mathrm{CH}=\mathrm{CH}-$ (olefinic protons), at $\delta 4.2$ due to aliphatic protons $\left(-\mathrm{CH}_{2} \mathrm{OCO}\right)$ group, at $\delta 1.7$ due to two methyl groups of bisphenol-A, and at $\delta 1.2$ due to protons of $-\mathrm{CH}_{2}$ group. 


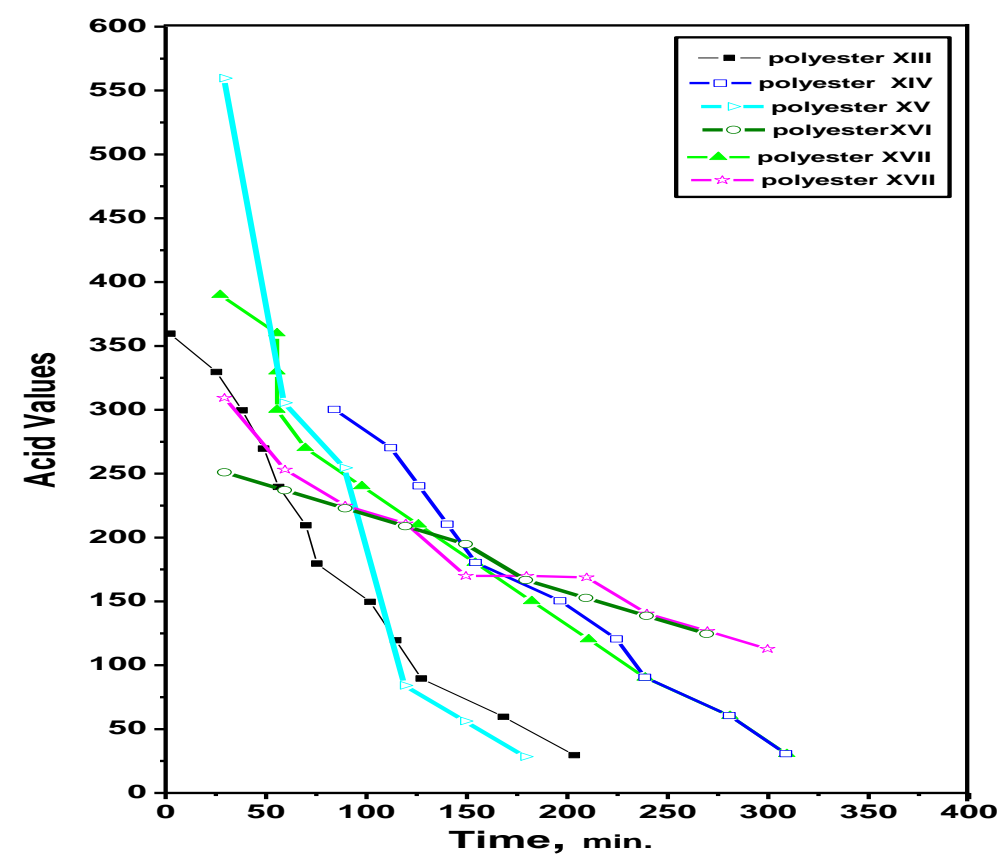

Fig. 4. The acid number versus time for unsaturated copolyesters resin (XIII-XVIII).

Physical properties of unsaturated copolyester resins

The prepared copolyesters (XIII-XVIII) were yellowish to dark brown viscous materials, soluble in various organic solvents except alcohol, n-hexane and light petroleum. The copolyesters prepared show great resistance to gelation after long storage periods. Some of the physical properties of the prepared copolyesters are illusterated in Table 4. From Table 4 it is clear that molecular weight of the prepared copolyesters resins ranged from 890 to 4007 .

TABLE 4. Physical properties of unsaturated polyester resins (XIII-XVIII).

\begin{tabular}{||c|l|c|c|c|c||}
\hline \hline Polyester & Nature of polyester & Mol. wt & $\begin{array}{c}\text { Acid } \\
\text { value }\end{array}$ & $\mathbf{n}$ & $\eta_{\text {int }}$ \\
\hline \hline XIII & Viscous material & 4007 & 2.26 & 85.6 & 0.0245 \\
\hline XIV & Low melting solid & 1002 & 112.22 & 1.9 & 0.0445 \\
\hline XV & Viscous material & 4007 & 28.05 & 8.3 & 0.0381 \\
\hline XVI & Low melting solid & 890 & 126.1 & 1.8 & 0.011 \\
\hline XVII & Viscous material & 4007 & 28 & 7.8 & 0.0682 \\
\hline XVIII & Low melting solid & 1336 & 84.1 & 2.5 & 0.0745 \\
\hline
\end{tabular}




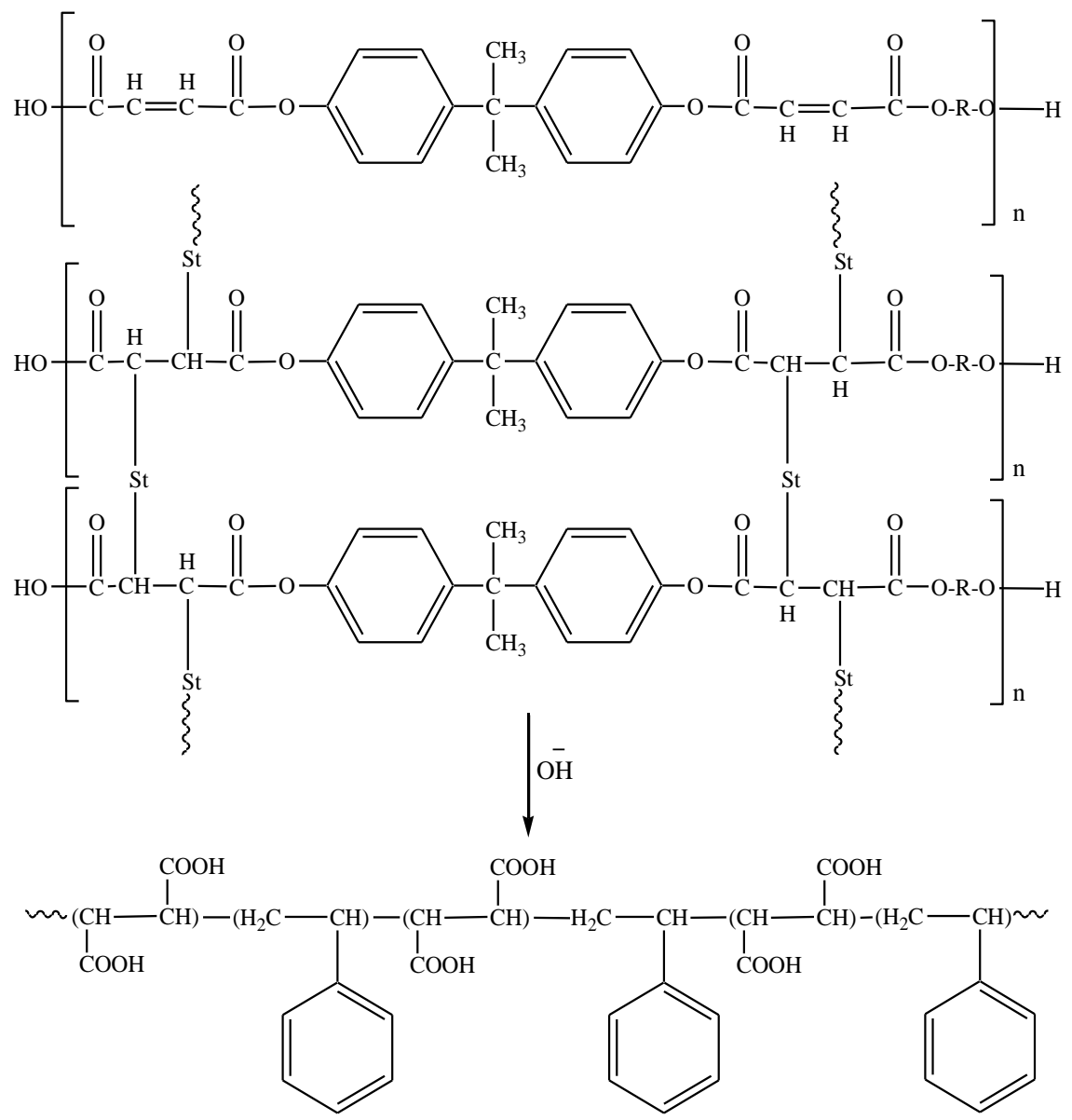

Where

$$
\begin{array}{cc}
\mathrm{R}=\mathrm{XIX}, & -\mathrm{CH}_{2}-\mathrm{CH}_{2-} \\
\text { XX, } & -\mathrm{CH}_{2} \mathrm{CH}_{2} \mathrm{OCH}_{2} \mathrm{CH}_{2^{-}} \\
\text {XXI, } & \mathrm{H} \\
-\mathrm{C}-\mathrm{CH}_{2-} \\
\stackrel{\text { I }}{\mathrm{C} \mathrm{CH}_{3}} \\
\text { XXII, }-\mathrm{CH}_{2}-\mathrm{CH}_{3} \mathrm{CH}_{-}-\mathrm{CH}_{2} \\
\text { XXIII, }-\mathrm{CH}_{2} \mathrm{CH}_{2} \mathrm{CH}_{2} \mathrm{CH}_{2} \mathrm{CH}_{2-} \\
\text { XXIV, }-\mathrm{CH}_{2} \mathrm{CH}_{2} \mathrm{CH}_{2} \mathrm{CH}_{2} \mathrm{CH}_{2} \mathrm{CH}_{2}
\end{array}
$$

Curing of unsaturated copolyester resins with styrene

The prepared unsaturated copolyesters (XIII-XVIII) were found to cure with styrene (St) to form insoluble crosslinked polymers (XIX-XXIV). The properties of these cured polyesters in the form of films showed that they have a considerable good film properties on glass and metal plates as shown in Table 5.

Egypt. J. Text. Polym. Sci. Technol. 14, No. 2 (2010) 
SYNTHESIS, CHARACTERIZATION AND BIOLOGICAL ACTIVITY ..

Egypt. J. Text. Polym. Sci. Technol. 14, No. 2 (2010) 
The cured polyesters were subjected to hydrolysis, and the hydrolyzate products (styrene-fumaric acid copolyesters) were characterized by IR and ${ }^{1}$ HNMR spectra. Thus, their IR spectra showed bands at $3500 \mathrm{~cm}^{-1}$ of $v_{\mathrm{OH}}$, at $3020 \mathrm{~cm}^{-1}$ of $v_{\mathrm{CH}}$ aromatic, at $1720 \mathrm{~cm}^{-1}$ of $v_{\mathrm{C}=\mathrm{O}}$ and $750 \& 700 \mathrm{~cm}^{-1}$ of aromatic five adjacent protons respectively. Also, their ${ }^{1} \mathrm{HNMR}$ spectra showed signals at $\delta 6.5$ to $\delta 7.2(\mathrm{~m}, 8 \mathrm{H})$ due to phenyl protons of styrene units and at $\mathrm{s} 1$ to 2.5 (broad) due to the aliphatic protons in fumaric and styrene units.

\section{Flamability test}

Flamability test was used to evaluate the fire retardancy of polyesters (I-XII) as varnish films. Table 6 illustrates the time of burning of coated polywood strips. From Table 6 it is clear that the time of burning of coated polywood strips is greater than that of uncoated polywood strips. It is attributed to the presence of the aromatic moiety and the halogen atoms in the polyester backbone which increase the resistance to flammability. ${ }^{(18)}$

TABLE 6. Time of burning of polyesters (I-XII) as varnish films.

\begin{tabular}{||l|l||}
\hline Polyester & Time (min.) \\
\hline I & 1.9 \\
\hline II & 2.7 \\
\hline III & 3.07 \\
\hline IV & 2.9 \\
\hline V & 2.5 \\
\hline VII & 3.07 \\
\hline VIII & 4.9 \\
\hline IX & 5 \\
\hline X & 5.03 \\
\hline XII & 5.01 \\
\hline Uncoated strip & 1.05 \\
\hline
\end{tabular}

\section{Antimicrobial activity}

The antimicrobial activity of the synthesized compounds was determined in vitro using the hole plate and filter paper method ${ }^{(20)}$ against a gram +ve and gram -ve bacteria. The tested compounds were dissolved in DMSO, different concentration have been chosen $(150,200$ and $250 \mu \mathrm{g} / \mathrm{ml})$. The inhibition zones of microbial growth produced by different compounds were measured in millimeters at the end of an incubation period of $48 \mathrm{hr}$ at $28^{\circ} \mathrm{C}$. DMSO alone showed no inhibition zone. The gram -ve bacteria were Escherichia coli, Strepto bacillus and the gram +ve bacteria were Staphylococcus aureus, Bacillus subtilis. The results are illustrated in Table 7 . The investigation of antibacterial screening data revealed that all tested compounds showed moderate to good activity compared to the broad spectrum antibacterial drugs used. It has been observed that most of the synthesized compounds have remarkable antimicrobial activity towards the selected bacteria 
SYNTHESIS, CHARACTERIZATION AND BIOLOGICAL ACTIVITY ..

TABLE 7. Biological activity of some polyesters.

\begin{tabular}{|c|c|c|c|c|c|c|c|c|}
\hline Compound & \multicolumn{4}{|c|}{ Gram (-ve) bacteria } & \multicolumn{3}{c|}{ Gram (+ve) bacteria } \\
\hline \multirow{2}{*}{ No } & \multicolumn{2}{|c|}{ Escherchia coli } & \multicolumn{2}{|c|}{ Streptobacillus } & \multicolumn{2}{|c|}{$\begin{array}{l}\text { Staphylococcus } \\
\text { aureus }\end{array}$} & \multicolumn{2}{c|}{$\begin{array}{c}\text { Bacillus } \\
\text { subtilis }\end{array}$} \\
\cline { 2 - 10 } & MIC & A & MIC & A & MIC & A & MIC & A \\
\hline I & 250 & + & 200 & + & 150 & + & 150 & + \\
\hline III & 250 & ++ & 150 & + & 150 & ++ & 150 & +++ \\
\hline IV & 150 & + & 200 & + & 200 & + & 250 & ++ \\
\hline VII & 150 & ++ & 150 & ++ & 250 & + & 250 & + \\
\hline IX & 150 & ++ & 150 & ++ & 200 & ++ & 200 & ++ \\
& & + & & & & & & \\
\hline XII & 150 & ++ & 200 & + & 150 & + & 150 & + \\
\hline XIII & 150 & ++ & 150 & ++ & 200 & + & 150 & ++ \\
\hline XV & 200 & ++ & 200 & + & 150 & ++ & 200 & + \\
\hline XVI & 150 & ++ & 150 & +++ & 200 & ++ & 150 & ++ \\
& & + & & & & & & + \\
\hline
\end{tabular}

$\mathrm{A}=$ antimicrobial activity of tested compounds

$(+,++$ and +++$)$ represent the exent of the zone diameter $(\mathrm{mm})$ inhibition of either fungal growth or bacterial cell.

(-) no inhibition was observed.

(+) $75 \mathrm{~mm}$, slightly active.

$(++) 77 \mathrm{~mm}$, modelatly active.

(+++) $79 \mathrm{~mm}$ highly active

$\mathrm{MIC}=$ minimum inhibitory concentration.

Nutrient agar medium have been utilized for growing test organisms.

(DMF) was used as control for each comparison.

\section{References}

1. Wetherill, Y.B., Petre, C.B., Mank, K.R., Puga, A. and Knudsen, K.E., The Xenoestrogen Bisphenol A Induces Inappropriate Androgen Receptor Activation and Mitogenesis in Prostatic Adenocarcinoma Cells, Mol.Cancer Ther, 1, 515-524 (2002).

2. Maffini, M.V., Rubin, B.S., Sonnenschein, C. and Soto, A.M., Endocrine disruptors and reproduct.ive health: The case of bisphenol-A., Molecular and Cellular Endocrinology, 254, 179 (2006).

3. Susiarjo, M., Hassold, T.J., Freeman, E., Hunt, P.A. and Bisphenol, A., exposure in utero disrupts early oogenesis in the mouse, PLoS Genetics, 3, 63-70 (2007).

4. Markey, C.M., Michaelson, C.L., Sonnenschein, C. and Soto, A.M., Alkylphenols and bisphenol A as environmental estrogens., In: Metzler M (Ed.), The Handbook of Environmental Chemistry. Part L, Endocrine Disruptors-Part I, vol. 3. SpringerVerlag, Berlin Heidelberg, 129-153 (2001).

5. Ricupito, A., Dell Pozzo, G., Diano, N., Grano, V., Portaccio, M., Marino, M., Bolli, A., Galluzzo, P., Botempo, P., Mita, L., Altucci, L. and Mita, D.G., Effect of bisphenol A with or without enzyme treatment on the proliferation and viability of MCF-7 cells, Environment International, 35, 21-26 (2009). 
6. Liaw, D., and Chang, Preparation and properties of flame-retardant polycarbonates and copolycarbonates from 3,3',5,5' tetrabromobisphenol AF and bisphenol $A$. Polymer, 38, 5545-5550(1997).

7. Ping, Z., Linbo, W. and Bo-Geng, L., Thermal stability of atromatic polyesters prepared from diphenolic acid and its esters. Polym. Degrad. Stab., 94, 1261 - 1266 (2009).

8. Honkhambe, P.N., Bhairamadgi, N.S., Biyani, M.V., Wadgaonkar, P.P. and Salunkhe, M.M., Synthesis and characterization of new aromatic polyesters containing cardo decahydronaphthaline groups, Eur.Polym.J., 46, 709 (2010).

9. Herman, F.M., Polyanhydrides synthesis Encyclopidia of Polymer Science and Technology, Interscience, New York, 7, 369 (2004).

10. Parkyn, B., Lamb, F. and Clifton, B.V., Polyesters: Unsaturated Polyester and Polyester Plasticizers, Iliffe, London, 2 (1969).

11. Charlston, E.F., Johnson,G.B., Lum, F.G., Higgins,D.G. and Park, K.T., Isophthalic Acid in Unsaturated Polyesters, Ind.Eng.Chem., 51, 253(1959).

12. Shabaan, A.F., El-Safty, M.A., Moustafa, H.Y. and Messiha, N.N., Structure and Properties of Saturated and Unsaturated Copolyesters Based on Bis-1,3(dicarboxymethoxy) benzene, J.Polym.Mater., 5, 185-192 (1988).

13. Essawy, S.A., El-Sawy, A.A., Mahmoud, A.A. and Badr, S.K., Synthesis and characterization of saturated and unsaturated copolyesters based on bis-1,4 (dicarboxymethoxy) benzene, J.Applied polymer Science, 45, 1727-1732 (1992).

14. Habacher, M.H., Doernberg, S. and Horner, A., Bis(p-hydroxyphenyl)acetic acid, J.Am. Pharm, Assoc., 42,23 (1953).

15. Ghanem, N.A., Nosseir, M.H. and Hussein, N.I., Crosslinking and degradation of a side-chain-unsaturated polyester, Eur.Polym. J. 7, 943 (1971).

16. Indian Standard Specifications, Indian Standard Institution, New Delhi, India, 158 (1950).

17. Gardner, A. and Sward, G., Physical and Chemical Examination of Paints,Varnishes, Lacquers and Colours, Gardner Laboratory, Bethesda, MD, 514 (1947).

18. Fijolka, P. , Lenz, I. and Runge, F., Analytische untersuchungsmethoden für polyester carboxylgruppenbestimmung, Makromol. Chem 23, 60 (1957).

19. Liaw, D. and Chang, P., Preparation and properties of flame-retardant polycarbonates and copolycarbonates from 3,3',5,5'-tetrabromo-bisphenol $\mathrm{AF}$ and bisphenol $A$, Polymer, 38, 5545(1997).

20. Leifiert, C., Li., H., Chidburee, S., Hampson, S., Workman, S., Digel, D., Epton, H.A.S. and Harbour, A., Antibiotic production andbiocontrol activity by Bacillus subtilis CL 27 and Bacillus pumilus CLAS. J. Appl.Bacteriol., 78, 97(1995).

(Received 19/7/2010; accepted 20/10/2010)

Egypt. J. Text. Polym. Sci. Technol. 14, No. 2 (2010) 


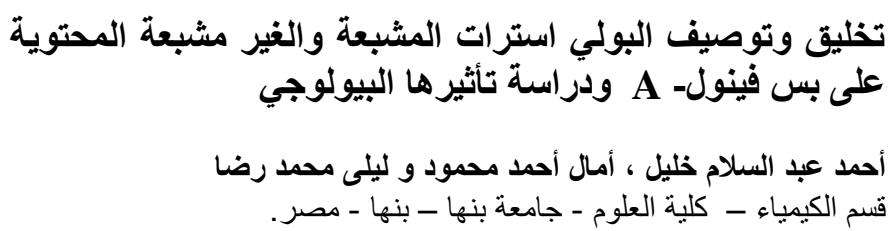

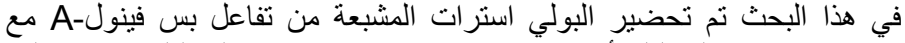

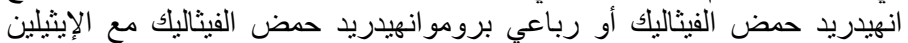

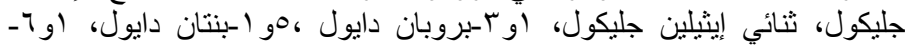

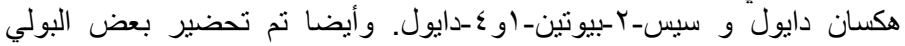

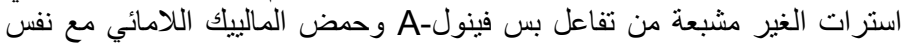

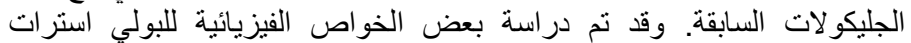

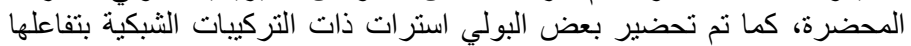

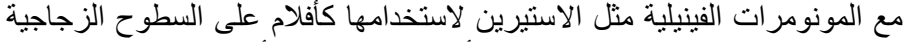

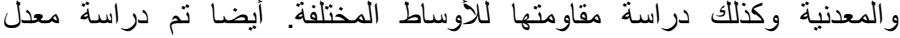

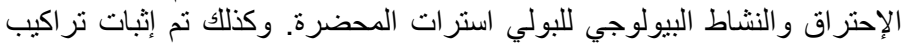

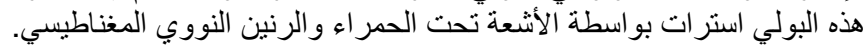


AHMED ABD-ELSALAM KHALIL et al.

Egypt. J. Text. Polym. Sci. Technol. 14, No. 2 (2010) 